\title{
Sporadic Breast Tumor Mutation
}

National Cancer Institute

\section{Source}

National Cancer Institute. Sporadic Breast Tumor Mutation. NCI Thesaurus. Code

C19422.

Any change in the DNA sequence of a breast tumor susceptibility gene that is not found in the parental samples. 